\title{
Article 23 of the Hong Kong Basic Law: Whither Media Freedom?
}

\author{
By Benjamin Lotz, Hamburg*
}

\section{A. Introduction and General Setting}

From the turmoil during the warlord period in the early years of the young Republic of China and the Chinese civil war to the vicissitudes of the Cultural Revolution in the late 1960s and the civil war in South Vietnam - on many occasions in history Hong Kong has proved to be a safe haven for regime opponents and the politically persecuted. ${ }^{1}$ Its unmatched economic freedom ${ }^{2}$, the respect for civil liberties ${ }^{3}$ and its pluralized and open media landscape ${ }^{4}$ further contributed to the city's reputation for freedom. ${ }^{5}$

However, faith in the rule of law and the prevalence of liberalism significantly shrank when sovereignty over Hong Kong was passed to its motherland, the People's Republic of China (PRC), in $1997 .^{6}$ Despite the assurance that the former colony will enjoy the status of a "Special Administrative Region" (SAR) and as such will be granted a "high degree of autonomy", doubts have been raised as to whether the South Chinese metropolis will be able to maintain its own legal and economic system. Be it through direct intervention or

Benjamin Lotz, Dr. jur. LL.M.(Hong Kong University), member of the Chinese European Legal Association e.V. E-mail: benjamin.lotz@law-school.de

This especially applies to the aftermath of the US-Vietnam war, see for example Harold Chang, 5,000 on way to HK in Vietnamese Armada, SCMP, June $25^{\text {th }}, 1977$, p. 1.

2 See for example Yasheng Huang, The Economic and Political Integration of Hong Kong: Implications for Government-Business Relations, in: Warren I. Cohen/ Li Zhao (eds.), Hong Kong Under Chinese Rule, The Economic and Political Implications of Reversion, Cambridge 1997, p. 96 (110); see also recent studies of conservative think tanks like the Heritage Foundation, "2011 Index of Economic Freedom", http://www.heritage.org/index/country/HongKong, or the Fraser Institute, "Economic Freedom of the World, 2011 Annual Report", http://www. freetheworld.com/2011/reports/world/EFW2011_complete.pdf, which both rank Hong Kong's economy as the freest in the world.

Referring to Hong Kong's human rights regime which has been complemented by the Hong Kong Bill of Rights in 1991, see note 48.

For details on the local media industry see below C. II.

5 See for example Anthony Spaeth, Hong Kong Has a Passion for Politics, Time Magazine, September $6^{\text {th }}, 2004$, http://www.time.com/time/magazine/article/0,9171,501040913-692963,00.html.

In the run-up to the handover the cover of Fortune Magazine, for example, apprehensively read "The Death of Hong Kong”, June $26^{\text {th }}, 1995$.

Art. 2 of the Basic Law and chapter 3 para. 2 of the Sino-British Joint Declaration, International Tax and Business Lawyer 5 (1987), pp. 424 - 441; for details on the drafting process of the Basic Law see Norman Miners, The Government and Politics of Hong Kong, Oxford 1991, pp. 3 et seq. 
more subtle exertion of influence, under the rule of the somewhat authoritarian ${ }^{8}$ governmental system in Beijing many saw accustomed freedoms jeopardized and, more generally, felt their liberal way of life could soon be undermined. On July $1^{\text {st }}, 2003$, six years after the resumption of power by the PRC, these concerns culminated in the biggest demonstration Hong Kong had seen since the 1980s: About 500,000 people ${ }^{9}$ voiced their disapproval with the introduction of security laws pursuant to Art. 23 of the Basic Law ${ }^{10}$ (BL), Hong Kong's quasi-constitution $^{11}$. This provision, which had already been contentious in the very beginning of its inception during the Basic Law drafting phase, reads:

"The Hong Kong Special Administrative Region shall enact laws on its own to prohibit any act of treason, secession, sedition, subversion against the Central People's Government, or theft of state secrets, to prohibit foreign political organizations or bodies from conducting political activities in the Region, and to prohibit political organizations or bodies of the Region from establishing ties with foreign political organizations or bodies."

The named criminal offences such as "subversion" or "theft of state secrets" were feared to be misused as a tool for political suppression and encroachment on critical media coverage. ${ }^{12}$ It thus came to no surprise that, next to leaders of opposition parties and civil rights advocates, journalists were at the forefront of the protests. They perceived the legislation as prescribed by Art. $23 \mathrm{BL}$ as the so far most serious challenge to freedom of press in the SAR. ${ }^{13}$

Although the bill was eventually withdrawn, the issue is far from settled: Indeed, the SAR remains under the constitutional obligation to reform its criminal law in keeping with Art. 23 BL. Considering the city's prominent position as a location of international media

Different terms emerged so as to describe the evolving style of governance in the PRC. Peerenboom, for example, speaks of "neo-authoritarianism", Michigan Journal of International Law 23 (2002), pp. 471 et seq. According to Sven-Michael Werner the PRC does not pursue the rule of law but the rule by law, Recht im Systemwandel: Ein Land, zwei Systeme und das Kontinuitätsproblem in Hongkong, Frankfurt am Main 2004, p. 95, mit Verweis auf Eric Wills Orts, The Rule of Law in China, Vanderbilt Journal of Transnational Law 34 (2001), p. 43 (93). See Miners, note 7, p. 27.

Officially titled "Basic Law of Hong Kong Special Administrative Region of the People's Republic of China”, ILM 29 (1990), pp. 1519 - 1551.

11 The term has gained currency in public discourse. The same applies to "mini-constitution", see for example Conrad, Interpreting Hong Kong's Basic Law: A Case for Cases, UCLA Pacific Basin Law Journal 23 (2006), p. 1 (2, 6).

12

National security in many cases turns out to be no more than "disguised attempts by a favoured class, ethnic group, or political-military elite to seize some advantage for itself", according to Larence Lustgarten/ Ian Leigh, In from the Cold: National Security and Parliamentary Democracy, Oxford 1994, p. 8.

13

Joint Report of the Hong Kong Journalists Association and the NGO Article 19, The Ground Rules Change: Freedom of Expression in Hong Kong Two Years After the Handover to China, June 1999, p. 6. Elsie Leung described this notion as a „,knife put over the head“" as long as the necessary legal amendments have not taken place, Sing Pao, December $16^{\text {th }}, 2004$, p. 4. 
corporations, its former reputation to host "the freest press in Asia" "14 , as well as the important role free media are playing in the SAR's broader political context, an Art. 23 legislation which wisely balances the interest in national security and the concern for a free press today constitutes one of the major legislative challenges faced by the Hong Kong government. Against the background of the underlying legal-political concept of "One Country, Two Systems", this paper seeks to introduce to one of the most contentions provisions in Hong Kong's still young constitutional system. It will look back at the 2003 National Security (Legislative Provisions) Bill ${ }^{15}$ (hereinafter also referred to as "Security Bill"), highlight some of the impact it would have had on press freedom ${ }^{16}$ and the local media landscape, and it will point to conclusions to be drawn for a future security legislation in line with Art. 23 BL.

\section{B. Constitutional Framework}

\section{Implementation of "One Country, Two Systems" Through the Basic Law}

The debate about Art. $23 \mathrm{BL}$ and the proposed legislation are closely connected to the legislative relationship between Hong Kong and the central PRC government under the doctrine of "One Country, Two Systems" (OCTS). ${ }^{17}$ OCTS is believed to bear greater relevance to the issue of Art. 23 than to any other constitutional debate in post-1997 Hong Kong. ${ }^{18}$ It can be regarded as a theoretical substructure and an organizing principle of the Hong Kong constitutional system. At the same time OCTS helps the PRC to pursue its "one China policy" and to bridge ideological gaps ${ }^{19}$ between the mainland and the erstwhile colonies Hong Kong and Macao.

See for example Doreen Weisenhaus, Article 23 and Freedom of the Press: A Journalistic Perspective, in: Fu Hualing/ Carole J. Petersen/ Simon N. M. Young (eds.), National Security and Fundamental Freedoms, Hong Kong 2005, p. 277 (278); Pierre Cayrol, Hong Kong - In the Mouth of the Dragon, Rutland 1998, p. 89.

Introduced to the Hong Kong Legislative Council on February $2^{\text {nd }}, 2003$.

As guaranteed in Art. 27 BL and Art. 39 BL.

This context of Art. 23 BL is also emphasized by Kelley Loper, A Secession Offence in Hong Kong and the "One Country, Two Systems" Dilemma, in: Fu Hualing/ Carole J. Petersen/ Simon N. M. Young (eds.), National Security and Fundamental Freedoms, Hong Kong 2005, p. $189(189,190)$.

See Loper, note 17, p. 189 (189). For the importance of OCTS for the issue of Art. 23 BL see also Tony Yuen Tat-Tong, The Freedom of Expression and Article 23 of the Basic Law, Hong Kong Student Law Review 3 (1997), p. 188 (190); Priscilla Mei-fun Leung, The Practical Necessity of Enacting Legislation Pursuant to Article 23, Hong Kong Lawyer, November Issue (2002), pp. 34 et seq. 
What OCTS exactly entails is laid down in the SAR's "mini-constitution",20, the Basic Law. Implementing OCTS the Basic Law serves as an interface ${ }^{21}$ between Hong Kong and the mainland by providing for the separation and linkage of both systems at the same time. ${ }^{22}$ Most fundamentally, the "two systems" are reflected in the preamble of the Basic Law, which states "that under the principle of 'one country, two systems', the socialist system and policies will not be practised in Hong Kong", and according to Art. 5 BL "the previous capitalist system and way of life shall remain unchanged for 50 years". ${ }^{23}$ Then again, the aspect of "one country" is stressed for example by Art. 1 BL which points out that the SAR "is an inalienable part of the People's Republic of China".

A significant constraint on Hong Kong's autonomy can be found in Art. 158 para. $1 \mathrm{BL}$ and Art. $159 \mathrm{BL}$ which vest the power of interpretation and amendment of the Basic Law with the Standing Committee of the National People's Congress. ${ }^{24}$ As early as in $1997^{25}$

As indicated above, the term has become current in academic debate on the Basic Law, see for example Albert Hung-yee Chen/ Anne S. Y.Cheung, Debates About the Rule of Law in the Hong Kong Special Administrative Region: 1997 - 2002, Hong Kong 2002, p. 1 (2); Conrad, note 11, p. $1(2,6)$.

See Chan, note 19, p. 407 (408). .

Fu Hualing points out the Basic Law's “dividing and bridging functions”, Supremacy of a Different Kind: The Constitution, the NPC and the Hong Kong SAR, in: Johannes Chan/ Fu Hualing/ Yash Ghai (eds.), Hong Kong's Constitutional Debate: Conflict Over Interpretation, Hong Kong 2000, p. 97 (97). Conrad in this respect calls the Basic Law "schizophrenic", note 11, p. 1 (2).

With a view to the preamble of the Chinese constitution (CPRC) of 1982 which enshrines "China's socialist system" and due to the fact that Art. 1 CPRC describes the PRC as a "socialist state under the people's democratic dictatorship led by the working class", some experts have raised doubts on the Basic Law's constitutionality. See Fu Hualing, The Form and Substance of Legal Interaction Between Hong Kong and Mainland China: Towards Hong Kong's New Legal Sovereignty, in: Raymond Wacks (ed.), The New Legal Order in Hong Kong, Hong Kong 1999, p. $95(99,100)$. Clarke argues for an amendment of the CPRC so as to clarify the issue, Hong Kong under the Chinese Constitution, Hong Kong Law Journal 14 (1984), pp. 71 et seq. Others denied the existence of legal conflict with the CPRC stressing its political rather than legal character, see also Clarke, Hong Kong under the Chinese Constitution, in: Y.C. Jao/ Chi-Keung Leung/ Peter Wesley-Smith (eds.), Hong Kong and 1997: Strategies for the Future, Hong Kong 1990, p. 215 (229), or saw an amendment of the CPRC in the Basic Law itself, $L i$, The CentralHKSAR Legislative Relationship: A Constitutional Assessment, in: Raymond Wacks (ed.), The New Legal Order in Hong Kong, Hong Kong 1999, p. 163 (167).

Yash Ghai, The Imperatives of Autonomy: Contradictions of the Basic Law, in: Johannes Chan/ Lison Harris (eds.), Hong Kong's Constitutional Debates, Hong Kong 2005, p. 29 (40), describing these provisions as the "Achilles' heel" of Hong Kong's autonomy. Another provision giving the central government leverage on Hong Kong's legislative development can be seen in Art. 18 para. $3 \mathrm{BL}$ which allows national laws to be applied in the SAR in a "state of emergency". A regular exemption from the general rule that mainland laws do not apply in the HKSAR is to be found in Art. 18 para. 2 and Annex III BL. However, so far the PRC has not yet made use of this provision, see Albert Hung-yee Chen, Constitutional Adjudication in Post-1997 Hong Kong, Pacific Rim Law \& Policy Journal 15 (2006), p. 627 (638). 
and $1999^{26}$ both these provisions triggered the first constitutional controversies which in turn exemplified the limits of the SAR's judicial, but also legislative, autonomy: Hong Kong courts were challenged with the legality of the so-called Provisional Legislative Council which the Standing Committee had established in the course of the handover ${ }^{27}$. Hence, Hong Kong judges faced the question of whether they see themselves entitled to adjudicate on acts of the Standing Committee of the National People's Congress. Whereas a pertinent authorisation of Hong Kong courts with respect to Art. 19 para. $1 \mathrm{BL}^{28}$ had been denied in the Ma Wai Kwan case ${ }^{29}$, the SAR highest Court, the Court of Final Appeal, in the Right of Abode cases ${ }^{30}$ held that it is in fact empowered by Art. 19 para. $1 \mathrm{BL}$ and Art. $82 \mathrm{BL}^{31}$ to strike down acts of the Standing Committee. In the latter case, however, the Standing Committee later "overruled" the Court of Final Appeal through a subsequent "legislative interpretation" Art. $22 \mathrm{BL}$ and Art. $24 \mathrm{BL}$ which were subject to the ruling in the Right of Abode cases and which deal with immigration matters, Art. 23 BL touches upon matters of national interest. The conflict between quasi-constitutional review via the Hong Kong Court of Final Appeal and the power to interpret the Basic Law of the Standing Committee might therefore well arise again when it comes to the introduction of security legislation in line with Art. 23 BL.

Furthermore, pursuant to Art. 17 para. 3 BL the Standing Committee may return Hong Kong laws ${ }^{34}$ if it finds them inconsistent with provisions of the Basic Law "regarding the

Less than a month after the handover. The judgment in the Ma Wai Kwan case (note 29) was rendered July $29^{\text {th }}, 1997$.

Yet, court cases related to the abode issue for example could be seen all across the first five years of the HKSAR.

Via the so-called Preparatory Committee for the SAR.

Art. 19 para. 1 BL: "The Hong Kong Special Administrative Region shall be vested with independent judicial power, including that of final adjudication."

HKSAR v. Ma Wai Kwan. The case was in essence a criminal case; it is regarded as a milestone towards judicial control of the Hong Kong legislature, Chen, note 24, p. $627(633,634)$.

$\mathrm{Ng} \mathrm{Ka}$ Ling v. Director of Immigration. Less attention has been drawn to a similar case: Chan Kam Nga v. Director of Immigration.

Art. 82 BL: „The power of final adjudication of the Hong Kong Special Administrative Region shall be vested in the Court of Final Appeal of the Region, which may as required invite judges from other common law jurisdictions to sit on the Court of Final Appeal.“

Rendered June $26^{\text {th }}$, 1999. For this mainland Chinese legal characteristic see Albert Hung-yee Chen, The Interpretation of the Basic Law - Common Law and Mainland Chinese Perspectives, Hong Kong Law Journal 30 (2000), p. 380 (408 et seq.).

A detailed review of the Right of Abode cases can be found, for instance, at Mark Elliot/ Christopher Forsyth, The Rule of Law in Hong Kong: Immigrant Children, the Court of Final Appeal and the Standing Committee of the National Peoples' Congress, Asia Pacific Review 8 (2000), pp. 53 et seq.

Which are then to be invalidated. 
relationship between the Central Authorities and the Region". Since Art. 23 BL relates to the enactment of laws protecting the security of the central government, it might well be characterized as just such kind of a provision. Consequently, particularly in combination with the power of interpretation pursuant to Art. 158 para. $1 \mathrm{BL}^{35}$, the Standing Committee enjoys a de facto veto power ${ }^{36}$ with respect to Art. 23 legislation. This is why some scholars have argued that the right of control of the Standing Committee deriving from Art. 17 para. 3, $158 \mathrm{BL}$ conflicts with Art. $23 \mathrm{BL}{ }^{37}$ According to them, the latter stipulates that the legislative power in the domain of national security resides exclusively with the SAR Hong Kong. Yet, Art. 23 BL merely places the SAR under the obligation to adopt laws on national security; it does not however vest the SAR with an exclusive legislative power. $^{38}$

\section{Article 23 of the Basic Law}

The provision covers two types of situations: First, it makes certain acts directed against the national interest punishable offences and, second, it sets constraints on the exertion of political influence by or by means of foreign political entities. Hence, Art. 23 BL aims both to protect the state against challenges from within the state and to cut links to and reduce influence capabilities of external actors. As for the first aspect, it seems questionable whether the wording "against the Central People's Government" merely refers to the executive branch or whether the prohibition of sedition, subversion, treason and secession extends to the whole state apparatus including the omnipresent Communist Party of China $(\mathrm{CPC})^{39}$. The government of the PRC cannot clearly be separated from the ruling party; as

35

36

39

The oftentimes somewhat hazy language of the Basic Law further enhances the power of interpretation, Dumbaugh, U.S. Role During and After Hong Kong's Transition, University of Pennsylvania Journal of International Economic Law 18 (1997), p. 333 (339).

Yee, Hong Kong and China in 1997: An Examination of Possible Legal and Economic Implications for United States Businesses, Santa Clara Law Review 36 (1996), p. 595 (622). According to Anna M. Han the Standing Committee could even repeal laws which do not contravene the Basic Law, Hong Kong's Basic Law: The Path to 1997, Paved with Pitfalls, Hastings International and Comparative Law Review 16 (1993), p. 321 (326); see also Albert Hung-yee Chen, Some Reflections on Hong Kong's Autonomy, Hong Kong Law Journal 24 (1994), p. 173 (176 et seq.).

Albert Hung-yee Chen, The Relationship Between the Central Government and the SAR, in: Peter Wesley-Smith/ Albert Hung-yee Chen (eds.), The Basic Law and Hong Kong's Future, Hong Kong 1988, p. 107 (126).

The wording of Art. 23 BL, "on its own", merely points out to a primary, yet not exclusive, legislative power. According to Carole J. Petersen Art. $23 \mathrm{BL}$ establishes an exemption from the general legislative power of the PRC in the domain of defence, Introduction, in: Fu Hualing/ Carole J. Petersen/ Simon N. M. Young (eds.), National Security and Fundamental Freedoms, Hong Kong 2005, p. 1 (1).

The CPC with its more than 70 million members is regarded the biggest political party in the world. 
a matter of fact the government arises out of CPC-internal proceedings. ${ }^{40}$ That is why "government" in the context of Art. 23 BL is not necessarily limited to a narrow, European understanding but rather relates to a broad array of state institutions and activities. ${ }^{41}$ Nonetheless, the range of protection to be afforded by the prescribed national security laws is limited by the general purpose of such kind of regulations which is the protection of fundamental and vital institutional structures of the state and the preservation of core organizational and political principles. ${ }^{42}$ Possible objects of the listed offences may therefore only be persons and institutions of certain relevance to the PRC as a whole ${ }^{43}$.

It remains to be stressed that Art. $23 \mathrm{BL}$ does not have any direct legal effect on the Hong Kong people but rather works as an "enabling provision" conferring the power to create pertinent laws on the SAR government ${ }^{44}$. Consequently, doubts have been raised as to whether Art. $23 \mathrm{BL}$ really sets out a constitutional obligation or whether it solely provides the SAR with the possibility to introduce and to make use of the named offences. The word "shall" however clearly conveys a constitutional obligation for the SAR ${ }^{45}$.

So as to preserve the existing judicial understanding of political crimes in Hong Kong, the local government would be well-advised to pass laws in accordance with its constitutional duty before the Standing Committee makes an interpretation pursuant to Art. $158 \mathrm{BL}^{46}$. By codifying the offences provided for in Art. $23 \mathrm{BL}$ in regular local ordinances, Hong Kong courts would not have to call on the Standing Committee in accordance with Art. 158 para. $3 \mathrm{BL}^{47}$ and instead would be given ample room for their own legal

40

41

42

43

44

46

47

For details of the PRC party system see Albert Hung-yee Chen, An Introduction to the Legal System of the People's Republic of China, $3^{\text {rd }}$ edition, Hong Kong 2004, pp. 74 et seq.

See also Tat-Tong, note 18, p. 188 (189).

Benny Y. T. Tai in this respect names the "state's essential interests" that are "sovereignty, territorial integrity, unity and national security", The Principle of Minimum Legislation for Implementing Article 23 of the Basic Law, Hong Kong Law Journal 32 (2002), p. 579 (581).

Colonial Hong Kong law on sedition had been harsher in the sense that, besides the British sovereign, it also included the Hong Kong government as a possible target.

See for example Fu Hualing, The National Security Factor: Putting Article 23 of the Basic Law in Perspective, in: Steve Tsang (ed.), Judicial Independence and the Rule of Law in Hong Kong, Hong Kong 2001, p. 73 (92).

Tai, note 42, p. 579 (581); Leung, note 18, pp. 34 et seq.

Priscilla Mei-fun Leung, The Hong Kong Basic Law: Hybrid of Common Law and Chinese Law, Hong Kong 2007, pp. 220 et seq.

Art. 158 para. 3 BL: "[...] However, if the courts of the Region, in adjudicating cases, need to interpret the provisions of this Law concerning affairs which are the responsibility of the Central People's Government, or concerning the relationship between the Central Authorities and the Region, and if such interpretation will affect the judgments on the cases, the courts of the Region shall, before making their final judgments which are not appealable, seek an interpretation of the relevant provisions from the Standing Committee of the National People's Congress through the Court of Final Appeal of the Region. When the Standing Committee makes an interpretation of the provisions concerned, the courts of the Region, in applying those provisions, shall follow the 
interpretation. In doing so, the courts would further be able to apply local standards and perceptions of press freedom.

\section{Press Freedom in the SAR Hong Kong}

\section{Legal Guarantees}

Free Media in Hong Kong are protected by different provisions to be found in international, constitutional as well as statutory law. Before being codified in the Hong Kong Bill of Rights ${ }^{48}$, press freedom was at times strictly regulated; in other periods it was handled quite liberally. After a rather authoritarian phase lasting until the $1960 \mathrm{~s}^{49}$, a free press awoke in a capitalistic setting and it was further boosted by the British in view of the expected return of Hong Kong to the PRC. ${ }^{50}$ The Bill of Rights, which in this regard served to ease political concerns, ${ }^{51}$ incorporated the International Covenant on Civil and Political Rights into Hong Kong law. In Art. 16 para. 1 it states that "everyone shall have the right to hold opinions without interference", and para. 2 of the same provision states that "everyone shall have the right to freedom of expression; this right shall include freedom to seek, receive and impart information and ideas of all kinds, regardless of frontiers, either orally, in writing or in print, in the form of art, or through any other media of his choice". 52 Art. 16 para. 3 (b) of the Bill of Rights allows for limitations on press freedom on grounds of "protection of national security". 53 On basis of this provision Hong Kong courts have developed a considerable body of case law. ${ }^{54}$ Yet, with the coming into force of the Basic

interpretation of the Standing Committee. However, judgments previously rendered shall not be affected."

Chapter 383, Hong Kong Bill of Rights Ordinance (No. 59), adopted on June $6^{\text {th }}$, 1991, in force since June $8^{\text {th }}, 1991$, ILM 30 (1991), pp. 1310 et seq. For the interplay with the ICCPR and the Basic Law, see Rao Geping, The Application of the International Covenant on Civil and Political Rights to Hong Kong, Pacific Rim Law and Policy Journal 2 (1993), pp. 9 et seq.

Yet, throughout the first decades under British rule Hong Kong experienced virtually unrestrained media, Fu Hualing, Past and Future Offences of Sedition in Hong Kong, in: Fu Hualing/ Carole J. Petersen/ Simon N. M. Young (eds.), National Security and Fundamental Freedoms, Hong Kong 2005, p. 217 (219).

See Anne S. Y. Cheung, Self-Censorship and the Struggle for Press Freedom in Hong Kong, The Hague 2003, pp. $57-64$.

51 See John Flowerdew, The Final Years of British Hong Kong: The Discourse of Colonial Withdrawal, New York 1998, pp. 66 et seq.

For the Bill of Rights see above, note 48.

For details on derogations from the ICCPR see Yash Ghai, Derogations and Limitations in the Hong Kong Bill of Rights, in: Johannes Chan/ Yash Ghai (eds.), The Hong Kong Bill of Rights: A Comparative Approach, Hong Kong 1993, pp. 392 et seq. For potential conflicts of the Bill of Rights with national security legislation see Tat-Tong, note 18, p. 188 (214 et seq.).

Chen, note 24, p. 627 (629). 
Law on July $1^{\text {st }}, 1997$, Art. 39 para. $1 \mathrm{BL}^{55}$ governs the applicability of the ICCPR in Hong Kong and provides the rules of the international agreement with a constitutional status ${ }^{56}$. This is why the importance of the Bill of Rights should in theory have shrunk. ${ }^{57}$ Yet, Hong Kong courts frequently continue to refer to the Bill of Rights in their decisions. ${ }^{58}$ Moreover, press freedom is listed in the Basic Law's own set of civil rights. According to Art. 27 BL "Hong Kong residents shall have freedom of speech, of the press and of publication".

\section{Significance}

For several reasons press freedom in Hong Kong is of extraordinary importance. Firstly, one needs to realize the city's role as a hub for the global and Asian media ${ }^{59}$ industry ${ }^{60}$. More than that, the scope and quantity of the Hong Kong media themselves are impressive: The SAR features the highest ratio of newspapers per capita and hosts one of the biggest press industries in the world ${ }^{61}$. More than 50 registered newspapers exist on the market, besides hundreds of other magazines and periodicals ${ }^{62}$. On top of that, there are six broadcasting corporations maintaining their own news departments ${ }^{63}$, seven Hong Kong based television channels and at least three different radio channels ${ }^{64}$. Given the sheer size of Hong Kong's media sector, the social and economic relevance of press freedom in the SAR becomes understandable. Yet, economic implications of restrictions on media coverage do not exclusively concern the media industry itself. A free flow of information is considered a

Art. 39 para. $1 \mathrm{BL}$ : "The provisions of the International Covenant on Civil and Political Rights, the International Covenant on Economic, Social and Cultural Rights, and international labour conventions as applied to Hong Kong shall remain in force and shall be implemented through the laws of the Hong Kong Special Administrative Region."

See Art. 8 BL and Art. 11 para. 2 BL which provide for the prevalence of the Basic Law in case of conflicts with Hong Kong statutory provisions.

See Johannes Chan, Hong Kong Human Rights Bibliography, Hong Kong 2006, p. iii.

The Bill of Rights remains applicable when it comes to cases concerning the compliance with laws enacted before the handover on July $1^{\text {st }}, 1997$, see Art. 8 BL.

The term "media" shall here extend to "different means and different types of organisation through which information and ideas about the world are made available to the public", see Howard Davies, Human Rights and Civil Liberties, Portland, Oregon 2003, p. 182.

Richard Cullen, Media Freedom in Chinese Hong Kong, The Transnational Lawyer 11 (1998), p. 383 (391). Weisenhaus describes Hong Kong as the "largest centre for international media operations in Asia", note 14, p. 277 (280).

Cullen, note 60, p. 383 (391).

62

More detailed information about media in Hong Kong can be found in the Hong Kong Yearbook 2008 , pp. 333 et seq.

Weisenhaus, note 14, p. 277 (280).

64

In addition numerous Hong Kong based channels today are broadcasted via the internet. 
prerequisite for fast communication as well as for flexibility and adaptability of management; it thus functions as an almost indispensable pillar of Hong Kong's capitalist market economy ${ }^{65}$. Other reasons for the special significance of press freedom in Hong Kong are to be found in the SAR's wider legal-political setting: Taking into account the fact that the Chief Executive, who heads the SAR, is ultimately appointed by the central government, the executive-led structure of the Hong Kong governmental system ${ }^{66}$ and the limitations of political autonomy provided for in the Basic Law, critical commentary and coverage serve as a watchdog on compliance with the OCTS principle. Furthermore, Hong Kong's media are vital to the checks and balances within the SAR itself. In absence of parties being able to seriously challenge the government in elections, the media at times have to fill in the role of the political opposition. Last but not least, in an environment where citizens are not legally entitled to claim access to information from the authorities, journalists help to make public the state's activities and at least partly satisfy peoples' inquiries. ${ }^{67}$

\section{National Security vs. Free Media - A Legislative Juggling Act}

The offences stipulated by Art. 23 BL seek to provide protection for the nation's fundamental interests but at the same time set restrictions on the right discussed above to unrestrained press coverage. ${ }^{68}$ The strongest repercussions for the work of journalists - positive or negative - are to be expected from the adoption of laws on "sedition" and "theft of state secrets". As opposed to "treason", "secession" or "subversion", both these crimes do not necessarily involve any act of violence or conspiratorial activity, but may be committed through not more than a news article, a TV documentary or any other form of publication. ${ }^{69}$

See for example Philip Bowring, Hong Kong as an International Commercial Centre, in: Warren I. Cohen/ Li Zhoa (eds.), Hong Kong under Chinese Rule: The Economic and Political Implications of Reversion, Cambridge 1997, pp. 8 et seq.

66

Albert Hung-yee Chen, "Executive-led Government", Strong and Weak Governments, and "Consensus Democracy”, in: Johannes Chan/ Lison Harris (eds.), Hong Kong's Constitutional Debates, Hong Kong 2005, p. 9 (10); Peter K. Yu, Succession by Estoppel: Hong Kong's Succession to the ICCPR, Pepperdine Law Review 27 (2000), p. 53 (65 et seq.).

67

68

69

The relationship between Art. $23 \mathrm{BL}$ and Art. $27 \mathrm{BL}$ has been regarded as determinant for the future of Hong Kong, see David Clark, Sedition and Article 23, in: Peter Wesley-Smith (ed.), Hong Kong's Basic Law: Problems and Prospects: Proceedings of a Seminar Held at the University of Hong Kong on 5 May, 1990, Hong Kong 1990, p. 31 (32).

See also Clark, note 68, p. 31 (33); Friedrich-Christian Schroeder, Der Schutz von Staat und Verfassung im Strafrecht: Eine systematische Darstellung, entwickelt aus Rechtsgeschichte und Rechtsvergleichung, München 1970, p. 320. 


\section{Sedition}

The common law concept of sedition as an offence of libel, i.e. a crime that is frequently based on expression of opinion, ${ }^{70}$ calls for a precise distinction from legitimate dissent. It would not be in compliance with the democratic alignment of the SAR's basic constitutional framework ${ }^{71}$ if each and every political opposition would constitute a punishable, because seditious, act. While security laws had been used relatively rarely under British governance $^{72}$ sedition was the one offence most frequently applied during riots and thereby also against the press, as, for instance, in 1951 against the Chinese-language $T a$ Kung $\mathrm{Pao}^{73}$. It thus comes to no surprise that the evolution of sedition in Hong Kong had always particularly correlated with control over the press. ${ }^{74}$ For these reasons sedition presents the most immediate and far-reaching danger to politically unrestrained reporting. ${ }^{75}$

The security legislation presented to LegCo in 2003 sought to completely repeal sec. 9 and sec. 10 of the Crimes Ordinance and to substitute both these provisions by a new set of regulations. ${ }^{76}$ The revised laws on sedition were by many perceived to be less restrictive compared with the existing body of rules and even compared with a proposed amendment of 1997 which had not become effective. ${ }^{77}$ Yet, the reform efforts were still considered insufficient and the respective provisions of the Bill have been subject to sharp criticism. ${ }^{78}$

70

71

72

73

74

76

77

78

As opposed to other legal systems based on Roman law, see Clark, note 68, p. 31 (34).

Pertaining to the ultimate aim of universal suffrage, see Art. 45 BL and Art. 68 BL.

See Weisenhaus, note 14, p. 277 (283). This equated to the general practice in Western countries, see $F u$, note 44 , p. 73 (75).

A newspaper funded by and, which like others, for example Wen Wei Po, regarded as a "mouthpiece" of the CPC, founded in 1902.

For the general effects of sedition on political journalism, see Alan J. Koshner, Founding Fathers and Political Speech: The First Amendment, the Press and the Sedition Act of 1798, Saint Louis University Public Law Review 6 (1987), p. 395 (404 et seq.); William T. Mayton, Seditious Libel and the Lost Guarantee of Freedom of Expression, Columbia Law Review 84 (1984), p. 91 (92, 109).

This view is shared by the Hong Kong Journalists Association which characterised the proposed provisions on sedition of the Security Bill as the "greatest threat to freedom of expression and press freedom" relating to written documents, Submission to the Legislative Council on the National Security (Legislative Provisions) Bill by the HKJA Executive Committee, April $7^{\text {th }}$, 2003. See also Weisenhaus, note 14, p. 277 (287).

Sec. 9 A - 9 D and a new chapter called "Enforcement Provisions Concerning Certain Offences Under Parts I and II"' (sec. 18 A - 18 E).

Weisenhaus, note 14, p. 277 (284); Chen, note 18, p. 80.

Similar concerns were voiced with respect to the Australian law on sedition. The bill was adopted after substantial amendments on December $5^{\text {th }}$, 2005. See for example Liz Jackson, Seditious opinion? Lock 'em up, http://www.abc.net.au/mediawatch/transcripts/s1489465.htm. 
The proposed wording of the substituting provisions was regarded as too fuzzy and undefined: ${ }^{79}$ Pursuant to sec. 9 A para. 1 (b) of the Bill as introduced to LegCo in July 2003 in its final version, somebody commits sedition if he incites others to engage in "violent public disorder" which would "seriously endanger the stability" of the PRC. It remains unclear what exactly should constitute such disorder and what threshold has to be reached so that the stability of the state is put at risk. Admittedly, these legal phrases aim to provide for unforeseen scenarios and thus help to maintain a necessary degree of openness. Yet, the terms still seemed to be overly broad and should be further determined by complementing remarks on both the required quantity and quality of the unrest incited. This could be achieved through a list of possible targets of disorder. It would have to be made clear what must be affected by the incited acts: The core governmental structures, the political system as a whole, the political decision-making process, facilities of infrastructural significance or even institutions which are highly relevant for the national economy? The list would at best be limited to objects which are of eminent importance and constitute basic pillars of the state; in respect to the Siracusa Principles ${ }^{80}$, it would not cover "local or relatively isolated threats to law and order" ${ }^{\prime \prime 1}$. Other disturbances should be covered by different offences protecting private and public property. Following the international trend of depolitization $^{82}$, one may also suggest that such kind of regulation should not be located in the section on national security ${ }^{83}$ but should instead stand among "non-political" offences governing the protection of public order and property. ${ }^{84}$

Another major point experts were demurring at was the lack of compliance with Principle 6 of the Johannesburg Declaration ${ }^{85}$ which stipulates that expression may only be punished if it "is intended to incite imminent violence", if the expression "is likely to incite such violence" and if "there is a direct and immediate connection between the expression

See Weisenhaus, note 14, p. 277 (285), with reference to "Response to the Consultation Document on the Proposals to Implement Article 23 of the Basic Law" published by the Hong Kong Bar Association December $9^{\text {th }}, 2002$, p. 18.

A declaration issued by the UN Economic and Social Council which established rules on the encroachment of freedoms granted by the ICPCR. Officially titled: Siracusa Principles on the Limitation and Derogation of Provisions in the International Covenant on Civil and Political Rights, UN Doc E/CN.4/1984/4 (1984), Human Rights Quarterly 7 (1985), pp. 3 - 14.

See I. B. vi. sec. 30 of the Siracusa Principles.

Cheung, note 50, pp. 147 et seq.

Part II of the Bill was titled "Endangering Security of the State".

See also "Response to the Hong Kong SAR Government Consulation Document on Proposals to Implement Article 23 of the Basic Law" submitted by Human Rights in China to the Legislative Council December $23^{\text {rd }}, 2002$, p. 7, http://www.hrichina.org/public/PDFs/Submissions/HRIC_ Article23-2002.pdf. 
and the likelihood or occurence of such violence". ${ }^{86}$ Whereas the first two requirements, the prerequisite of an intention to incite and a likelihood-test, had been integrated into the Bill, ${ }^{87}$ the third condition and others details were not reflected in the government's proposal. Thus, concerns were raised that the proposed legislation might not fully be in line with international standards. ${ }^{88}$ Yet, it is well possible that the requirement of "violence" and of a "direct and immediate connection" would undermine the purpose and efficiency of the sedition offence. Indeed, inciting propaganda or sabotage of the state computer system for instance, might have equal effects and constitute legitimate grounds for a criminal sanction. ${ }^{89}$ Therefore, so as to fulfill the duty according to Art. 23 BL, sedition must not be limited to the incitement of "imminent violence". More than that, the act of incitement must in fact be a proximate cause for treason, subversion, secession or violent disorder, but the demand for a "direct and immediate connection" seems doubtful since cases where a longer period of time passes by between the seditious act and its effects would otherwise not be covered. ${ }^{90}$ The government considered Principle 6 of the Johannesberg Declaration "unnecessarily restrictive" and caved in to its critics' demands only half-way. ${ }^{91}$ The concessions made in fact led to a reasonable compromise which could also be adopted by a future security bill.

After all, the Security Bill also faced criticism for retaining the offence of "handling seditious publications". From a journalist's perspective it seems particularly harsh that, pursuant to Art. $9 \mathrm{C}$ para. 2 (a) Crimes Ordinance, commission of this crime requires not more than publishing or displaying seditious publications. A "seditious publication" in turn is loosely defined as a publication that is likely to induce somebody to treason, secession or subversion. ${ }^{92}$ Even under consideration of the excuses provided for in Art. 9 D Crimes Ordinance, this regulation excessively narrows the latitude of critical commentary. For example, reports and comments levelling criticism at the PRC and its major policies, especially the practice of OCTS, could easily be interpreted as a likely incitement of secession. In addition, the provision lacked a subjective requirement, i.e. there would have been no

Chen, note 18 , p. 80.

See "intentionally" and "likely" in sec. 9 A para. 1 (a) and (b) of the Crimes Ordinance as proposed in the Bill.

See, for example, Weisenhaus, note 14, p. 277 (286).

See "Proposals to Implement Article 23 Broadly Consistent with Johannesburg Principles", sec. 8, issued by the Security Bureau in March 2003, LC Paper No. CB(2)1577/02-03(02). Yet, citing the example of deployment of biological and chemical weapons is insofar misleading as such an act would already be covered by other offences such as incitement to murder for instance.

The Security Bureau in this regard invoked the example of inciting a terrorist group to prepare a secessionist war, including arming itself with missiles or the like, note 89, sec. 11 (iii).

It also emphasized the practical difficulties in implementing Principle 6 of the Johannesburg Declaration stressing that no country has yet managed to bring its laws in line with the provision.

Art. 9 C para. 1 Crimes Ordinance. 
need to prove the intention of incitement on behalf of the journalist. The crime of "handling seditious publications" restrains journalism but does not serve any urgent demand for national security since publications which clearly cause others to commit the listed political offences would already be subsumed under the offence of sedition itself. By contrast, the Bill had dropped the "possession of seditious publications"93 as a crime. Yet, what looks like a step towards a more liberal security regime would still have to prove itself in practice because many acts could still fall under the aforementioned provision of Art. 9 C Crimes Ordinance. $^{94}$

\section{Theft of State Secrets}

The Security Bill arranged for a number of amendments to the current law governing the theft of state secrets, the Official Secrets Ordinance. It still raised concerns among journalists since some of the modifications would have extended the scope of the offence's applicability. The Art. 23 reform aimed to make disclosure of information deriving from illegal access ${ }^{95}$ a punishable act. The new provision ${ }^{96}$ targeted for example at situations in which computer hackers sell secret information to publishers and in which none of the involved parties would be liable to prosecution under the existing Official Secrets Ordinance. ${ }^{97}$ For that purpose, the Bill would have abolished the general prerequisite that the relevant information had to be obtained either as a public servant and government contractor respectively or with the aid of such a person. Coming into possession of precarious documents by means of "illegal access" would have been sufficient to carry the penalties as prescribed in sec. 25 of the Official Secrets Ordinance ${ }^{98}$. It is easily imagined that investigative journalists dealing with sensitive governmental documents may easily fall under such a criminal provision. Nevertheless, the condition of "illegal access" has been considerably tightened in the course of the consultation process and following discussions of the drafting committee. The initial concept of "unauthorized access" has been defined more precisely in the final version of the Bill as an illegal practice based on certain criminal offences like robbery, burglary or access to computer with criminal or dishonest intent. ${ }^{99}$ It is questionable whether this new offence would have been threatening to Hong Kong's media. While some regarded

Art. 10 para. 2 Crimes Ordinance (original version).

See Weisenhaus, note 14, p. 277 (286).

First more loosely delineated as "unauthorized access", see Chen, The Consultation Document and the Bill: An Overview, in: Fu Hualing/ Carole J. Petersen/ Simon N. M. Young (eds.), National Security and Fundamental Freedoms, Hong Kong 2005, p. 93 (107).

See sec. 18 para. 2 (d) of the revised Official Secrets Ordinance.

Chen, note 95, p. 93 (107).

Fines or two years of imprisonment.

See sec. 18 para. 5 A (a) of the revised Official Secrets Ordinance. 
the final version "acceptable", 100 others claimed it would have "changed the very nature of how journalists can be held liable". ${ }^{101}$ Whereas the protection of state secrets in scenarios as described above would already be assured by the respective "ordinary" crimes underlying the proposed new offence, ${ }^{102}$ journalists would have been disproportionately affected by such a provision. They would be forced by threat of imprisonment to scrutinize each single source for its legality. Although the element of mens rea stipulates that the perpetrator must have at least "reasonable cause to believe" that the information stems from one of the unlawful means described in sec. 18 para. $5 \mathrm{~A}$ of the proposed amended Official Secrets Ordinance, the provision would have put an unreasonable burden on journalists and thus have had a chilling effect on investigative media coverage. First, it is in some cases extraordinarily difficult to ascertain the absence of illegal behaviour; second, it would have been in the hands of the authorities to create a "reasonable cause to believe" on behalf of the journalist merely by announcing that the relevant information has been stolen or the like ${ }^{103}$. It caters to the legitimate interest in national security and the requirements of Art. $23 \mathrm{BL}$ to hold on to the offence of disclosure of information deriving from illegal access. So as to safeguard journalists from penalties however, the threshold for the subjective element would need to be raised to the level of actual knowledge.

Another major point of criticism voiced with regard to the aborted Security Bill concerned the introduction of a public interest defence which formerly had not existed in Hong Kong law. ${ }^{104}$ The eventual bill included a reference ${ }^{105}$ to public interest but made two restrictions ${ }^{106}$ : First, the disclosure must "not exceed the extent that is necessary for revealing" the matter concerned, and, second, the government stressed that the prohibition of disclosure of certain information might as well be in the public interest. It thus established a need to weigh both interests and decided to grant the defence only in case the public interest in revealing the information outweighs the public interest in keeping the information confidential. The first-named limitation on the defence of public interest was considered "too vague and too narrow". ${ }^{107}$ However, it only seems to parallel a widely acknowledged

100

101

Chen, note 95, p. 93 (110).

Weisenhaus, note 14, p. 277 (292)

With respect to the source. As for journalists, their acts could possibly be subsumed under the

103 See also Weisenhaus, note 14, p. 277 (292). offence of sedition or other regulations, such as for the protection of privacy for instance.

104 The government first refused to introduce such a defence on grounds of its alleged legal uncertainty. See the comment of the then Solicitor General Bob Allcock "Media Have No Reason to Fear", http://www.basiclaw23.gov.hk/english/focus/focus2.htm.

105 Sec. 18 para. 5 B of the proposed version of the Official Secrets Ordinance.

106 Sec. 18 para. 5 B (b) and (c) of the proposed Official Secrets Ordinance.

107 See para. 4 of the statement of the Article 23 Concern Group of July $8^{\text {th }}, 2003$, Article 23 Legislation - What Needs to Be Done, http://www.article23.org.hk/english/newsupdate/jul03/0708 concern_e.doc. 
teleological approach to limit the applicability of legal provisions and exemptions therefrom to what is necessary with respect to purpose of the provision and exemption respectively. From this perspective, it seems just consistent with a general concept of law to integrate a necessity-test. That is because disclosure of information cannot be justified as far as the defence of public interest in fact does not apply, even if it does so with regard to certain parts of the publication. By contrast, the second limitation on the defence seems questionable since weighing the opposing interests places immense uncertainty on journalistic activities. The culpability of political press articles or any other kind of media coverage would thus be hardly predictable. ${ }^{108}$ A future bill on national security should therefore stick to the named defence but abolish the second precondition of an overriding public interest.

\section{E. Conclusion}

Past debates about Art. 23 BL have illustrated more than any other issue which has arisen so far in the context of "One Country, Two Systems" the warring interests, the fears and hopes, and the constitutional ambiguities springing from Hong Kong's peculiar legal and political status. The provision will remain to be an issue for Hong Kong's media as long as the prescribed laws to prohibit crimes against the central government have not been enacted and proved to not curtail freedom of press. Art. 23 BL has therefore been considered a "ticking time bomb". 109

Yet, a closer look at the first attempt to introduce laws in accordance with Art. $23 \mathrm{BL}$ shows that in many ways a reform of laws dealing with political crimes would likely bring forth a more liberal approach to journalistic investigations and publicising. ${ }^{110}$ The Bill of 2003 would have led to a number of amendments which would have added legal barriers to the punishability of political dissent or which would have abolished outdated criminal provisions oftentimes originating in the colonial era of the $19^{\text {th }}$ century. Even the Standing Committee of the National People's Congress' far-reaching powers, particularly the power to make binding interpretations and repeal laws which it regards as incompatible with the Basic Law, and the limits to the right of final adjudication of the Court of Final Appeal as set in the Right of Abode cases in this regard are little cause for concern. The PRC as yet largely adhered to the separation of systems as laid down in the OCTS principle. ${ }^{111}$ Moreover, it needs to be taken into account that each future Art. 23 legislation will have to be applied by independent Hong Kong courts.

Cliff Buddle, If Only We'd Known Last Year, We Might Have Defused a Time Bomb, SCMP, March $21^{\text {st }}, 2004$, p. 12.

110 Likewise the Bill of 2003, however, a new bill will need to be scrutinized for shortcomings in 111 security aspects and in press freedom respectively.

See for example Kleeman, The Proposal to Implement Article 23 of the Basic Law in Hong Kong: A Missed Opportunity for Reconciliation and Reunification Between China and Taiwan, Georgia Journal of International \& Comparative Law 33 (2005), pp. 705 et seq. 